\title{
Biodiversity and taphonomy of the early Cambrian Guanshan biota, eastern Yunnan
}

This paper provides an overview of the early Cambrian Guanshan biota with emphasis on new information regarding its sedimentology, taphonomy, and biodiversity. The full extent and significance of this exceptionally preserved biota are also discussed.

The study is reported in Volume 53 of Science China Earth Sciences because of its significant research value.

Cambrian Burgess Shale-type fossil lagerstätten are crucial to understanding the early evolution of metazoan and ancient ecosystems. The discovery of the famous Chengjiang fauna has stimulated an ongoing search for more Burgess Shale-type lagerstätten around the world. The Guanshan biota is one of the most important Cambrian lagerstätten discovered in the final decade of the twentieth century in the Yangtze Platform, South China.

The age of the Guanshan biota is early Stage 4 of the Cambrian Series II (ca. 515-510 million years), which is slightly younger than the Chengjiang fauna. Exceptionally preserved soft-bodied fossils of the Guanshan biota occur in the Wulongqing Formation, which is wildly exposed in eastern Yunnan Province. Recent excavation conducted by a research group led by Hu Shixue has revealed abundant fossils with preserved soft-bodies, which would not be found in areas subject to normal depositional situations. Several fossil groups including the lobopods, eldonids, hyolithids with helens, and green algae were recovered for the first time. To date, more than ten fossil groups (arthropods, brachiopods, sponges, eocrinoid echinoderms, cnidarians, hyolithids, vetulicoliids, paleoscolecids, chancelloriids, anomalocaridids, lobopods, eldonoids, and green algae) have been recovered. The preservation of soft-tissues in some groups of the Guanshan biota, notably the trilobites and brachiopods, rivals that described from the well-known Chengiiang fauna and the Burgess Shale fauna in quality.

Another important advance made in this study is the sedimentology and taphonomy of the Guanshan biota. This work indicates that the exceptional fossil preservation of the Guanshan biota resulted from rapid smothering by distal storm sediments. The original environment of the Guanshan biota was a storm-dominated offshore transition between a fair-weather wave base and storm wave base, and was located within the photic zone.

In summary, the Guanshan biota is one of the most diverse and informative Burgess Shale-type fossil Lagerstätten, preserving the most complete picture of shallow marine diversity during Stage 4 of the Cambrian. The Guanshan biota fills the gap between the early Cambrian Chengjiang fauna and most middle Cambrian fossils Lagerstätten (e.g. the middle Cambrian Kaili biota, the Burgess Shale fauna, and the Utah fossil lagerstätten) and opens a new window on marine biodiversity and community dynamics before the early-middle Cambrian transition. Further research of the Guanshan biota may yield additional results that increase our understanding of the Cambrian Explosion and the evolution of early life.

The authors are affiliated with the State Key Laboratory of Palaeobiology and Stratigraphy, Nanjing Institute of Geology and Palaeontology, Chinese Academy of Sciences, Nanjing 210008, China and the Yunnan Geological Survey, Kunming 650051, China.

This work was supported by the National Basic Research Program of China (2006CB806401) and the National Natural Science Foundation of China (40772020, 40725005 and 40930211).

See the article: Hu S X, Zhu M Y, Steiner M, et al. Biodiversity and taphonomy of the early Cambrian Guanshan biota, eastern Yunnan. Sci China Earth Sci, 2010, 53: 1765-1773

Open Access This article is distributed under the terms of the Creative Commons Attribution License which permits any use, distribution, and reproduction in any medium, provided the original author(s) and source are credited. 